\title{
SOSOK WANITA BALI SEBAGAI INSPIRASI SENI LUKIS BERBASIS TEKNIK MIXMEDIA
}

\author{
Oleh: \\ Gede Yosef Tjokropramono \\ Fakultas Seni Rupa dan Desain \\ Institut Seni Indonesia (ISI), Denpasar \\ gedeyoz@yahoo.com
}

\begin{abstract}
In the process of painting, it is also necessary to apply a method in order to explain in detail the stages within the process of creation as the effort in building a work of art. The approaches are utilized during the process of the creation hence there can be description or explanation and responsibility logically and scientifically. In this painting using mixmedia, the activities of women are the initial idea, sspecially the role of everyday life of Balinese women. This is in the background by the demands that must be made by Balinese women to meet the needs of daily life and undergoing increasing customs. In making this painting, there is still a lot shortcomings, the creator hope that to remain useful for the development of painting. In this creative process is not likely to continue to develop both in theme and technique.
\end{abstract}

Keywords: balinese women, mixmedia technique

\begin{abstract}
Abstrak
Dalam proses penciptaan karya seni lukis ini, juga diperlukan suatu metode untuk menjelaskan secara rinci tahapan-tahapan dilakukan dalam proses penciptaan, sebagai upaya dalam membangunan sebuah karya seni. Pendekatan-pendekatan di maksudkan supaya selama dalam proses pencipta dapat dijabarkan atau dijelaskan dan bisa dipertanggung jawabkan secara logis dan ilmiah. Dalam karya lukis mixmedia ini aktivitas wanita merupakan gagasan awal. Teristimewa peranan kehidupan Wanita Bali sehari-hari. Hal tersebut dilatar belakang oleh adanya tuntutan yang harus dilakukan oleh kaum wanita Bali untuk memenuhi kebutuhan hidupnya sehari-hari dan menjalani adat-istiadat yang meningkat. Dalam pembuatan karya lukis ini masih banyak pencipta rasakan kekurangan-kekurangan, pencipta harapkan dapat tetap berguna bagi kepentingan perkembangan karya lukis. Dalam proses kreatif ini tidaklah tertutup kemungkinan untuk terus berkembang baik secara tema maupun tekniknya.
\end{abstract}

Kata kunci: wanita Bali, tehnik mixmedia

\section{PENDAHULUAN}

\subsection{Latar Belakang Masalah}

Manusia dengan akal budinya menciptakan sesuatu yaitu sebagai ungkapan rasa estetisnya yang merupakan hasil interaksi dengan lingkun- gan tempat ia berada. Sebagai seorang seniman yang berinteraksi dengan lingkungan alam sehari-hari, secara tidak langsung menimbulkan reaksi dalam diri berupa perasaan kagum, bahagia, sedih, marah, senang dan sebagainya yang berlanjut timbulnya insipirasi untuk dituangkan 
sebagai karya seni. Semakin peka mereka merespon lingkuingan, semakin banyak mendapatkan pengalaman baru yang dapat diungkapan. Hal tersebut seperti diungkapkan oleh Henry Matisse: Penciptaan dimulai dengan pengalaman. Peristiwa melihat itu sendiri merupakan penggalangan kreatif yang meminta banyak usaha.

Sebagai makhluk sosial yang berinteraksi dengan lingkungan tempat saya berada, saya mengamati aktivitas kehidupan manusia baik yang dilakukan oleh orang tua, kaum muda maupun anak-anak. Dari lingkungan terdekat umpama dalam satu keluarga, kita mengenal ibu yang penuh kasih sayang mendidik anakanaknya, mendampingi suami serta mengurus keperluan rumah tangga dalam aktivitas tersebut terlihat jelas betapa pentingnya peranan kaum wanita. Seperti halnya wanita Bali, selain kodratnya sebagai ibu yang mengurusi rumah tangga ia juga bekerja mencari nafkah. Ada yang bertani, menjadi nelayan, tukang batu, pegawai dan sebagainya dalam rangka memenuhi kebutuhan hidup keluarganya. Di samping itu juga ia memiliki tugas yang berkaitan dengan adat dan agama yang tidak dapat ditinggalkan. Dalam kehidupan sehari-hari upacara adat itu dilakukan hampir setiap hari, baik upacara Dewa Yadnya, Manusia Yadnya serta Pitra Yadnya dan peranan kaum Wanita sangat diperlukan mulai dari persiapan sampai dengan upacara selesai.

Dari berbagai aktivitas yang dilakukan oleh wanita Bali yang sangat menarik perhatian saya yaitu aktivitas wanita yang melakukan upacara adat. Dalam aktivitas tersebut saya melihat adanya gotong royong dan rasa kebersamaan yang dilakukan dengan penuh suka cita dan tanpa pamrih. Sikap dan gerak-gerik yang dilakukan sangat menarik perhatian dan merupakan momen estetis yang merangsang timbulnya ide untuk diwujudkan sehingga membutuhkan sarana untuk mengekspresikannya. Dalam hal ini saya mengekspresikan ide saya melalui karya seni lukis, Di samping itu juga untuk mendapatkan kemungkinan terus berkembang, baik secara tema maupun teknik.

Berdasarkan uraian di atas, saya dapat rumuskan masalah yang dibahas:

1. Bagaimana menyajikan bentuk profil sosok Wanita Bali ke dalam karyaseni.

2. Bagaimana fungsi seni lukis dengan menggunakan sarana mixmedia?
3. Bagaimana makna visualisasi Wanita Bali pada karya seni lukis dengan teknik mixmedia?

\subsection{Metode Penciptaan}

Dalam proses penciptaan karya seni lukis ini, juga diperlukan suatu metode untuk menjelaskan secara rinci tahapan-tahapan dilakukan dalam proses penciptaan, sebagai upaya dalam membangunan sebuah karya seni. Pendekatanpendekatan di maksudkan supaya selama dalam proses pencipta dapat dijabarkan atau dijelaskan dan bisa dipertanggung jawabkan secara logis dan ilmiah. Adapun terapan-terapan yang maksud adalah:

\subsubsection{Proses Penjajagan (Eksplorasi)}

Sebagai langkah awal dari suatu penciptaan suatu karya seni, tahap ini termasuk berpikir, berimajinasi, merasakan, dan merespon objek yang dijadikan sumber penciptaan.

\subsubsection{Eksperimentasi}

Eksperimen dalam proses melukis merupakan upaya untuk menemukan

hal-hal baru dan terkadang hasil dari eksperimen tersebut tidak terduga. Untuk mengungkapkan ide penciptaan yang telah ditetapkan, dikembangkan penggambaran sosok wanita Bali dengan cara mencoba-coba trial and error

Melakukan eksperimentasi, membuat sketsasketsa pada kertas gambar terlebih dahulu menggunakan pensil agar pengalaman-pengalaman yang terekam dalam memori, terstimulasi untuk menggali potensi imajinasi yang ada. Sketsa-sketsa yang di buat dalam hal ini, tidak serta merta ditransfer langsung untuk mewujudkan ke dalam karya, melainkan dipertimbangkan dengan cermat menyangkut ide, estetik, dan artistic bahkan ada kalanya sketsa tidak terpakai sama sekali, karena dianggap belum representatif dengan gagasan yang diinginkan.

\subsubsection{Persiapan (Preparation)}

Adapun persiapan-persiapan seperti alat dan bahan yang pencipta pergunakan yaitu bahanbahan. Adapun material yang digunakan dalam teknik mixmedia adalah sebagai berikut:

- Malam batik untuk membuat textur

- Kanvas yang digunakan berukuran minimal 100x $100 \mathrm{~cm}$.

- Cat acrilyc dan warna batik sebagai 
pewarna.

- Vernis sebagai penguat warna.

Alat- alat yang dipergunakan:

- Canting batik, kuas dengan berbagai ukuran.

- Pisau palet.

- Ember sebagai tempat mencampur warna batik

- Setrika sebagai alat penggosok untu meratakan/menggosok malam batik.

\subsubsection{Teknik}

Teknik yang pencipta gunakan dalam pembuatan karya seni mixmedia ini adalah dengan teknik canting dan kuas sapu menggunakan berbagai ukuran yakni diwarnai sesuai dengan keinginan. Di samping material dan peralatanya mudah didapat, cara tersebut lebih praktis dan juga tidak memerlukan tempat khusus.

Kelemahan dari sistim mixmedia ini adalah karya tidak boleh ditaruh ditempat yang panas karena sifat malam batikyang mudah meleleh. Sedangkan kelebihannya adalah unik dan mengasikkan.

\subsubsection{Tahap-tahap Perwujudan}

1. Membuat sket dasar (rencana kasar) di atas kertas yang berdasarkan atas ide yang akan dijadikan thema untuk diwujudkan. Kemudian disain tersebut dijadikan dasar atau patokan untuk dipindahkan ke permukaan kanvas. Setelah itu mulai menuangkan malam batik dengan canting dan mix dengan sapuan kuas. Setelah tercapai gambar yang diinginkan bisa langsung dilanjutkan ke proses pewarnaan.

2. Pencipta selalu memulai dengan memberi warna blok dasar gelap pada kertas dengan cara penintaan terlebih dahulu. Warna diratakan sehingga tercampur merata. Bila menginginkan warna lembut sedikit cair atau terlalu kental dengan mengatur volume campuran air. Cairan varnis ditambahkan apabila menginginkan warna cepat kering atau untuk mencapai efek tekstur.

Demikian penerapan teknik mixmedia ini pada karya seni lukis dapat dilakukan sebebas mungkin.

\section{II.PEMBAHASAN}

\subsection{Tinjauan Pustaka}

Keinginan berekspresi di dalam berkesenian adalah upaya untuk menciptakan suatu karya seni yang dilakukan secara sadar, seperti yang dikemukan oleh (Soedarso Sp, 1990: 11) "Seni adalah hasil karya manusia yang mengkomunikasikan pengalaman-pengalaman batin; Pengalaman batin tersebut disajikan secara indah atau menarik sehingga merangsang timbulnya pengalaman batin pula pada manusia lain yang menghayatinya". Penciptaan itu lahir disebabkan oleh kebutuhan seniman untuk mengkomunikasikan pengalaman estetis, kecintaan, kesukaan, perenungan, fantasi dan sebagainya yang tidak bisa lepas dari refleksi dan masalah-masalah dilingkungan yang didukung oleh faktorfaktor antara lain ide, pengalaman, penguasaan teknik, intelektual, dan penghayatan sebagai proses terwujudnya karya seni.

Dalam berkarya seorang seniman sudah tentu tidak dapat lepas dari pengaruh lingkungan, lingkungan tersebut dapat terwujud alam maupun masyarakat sekitarnya. Hal ini diungkapkan pula oleh Soedarso Sp, (1988: 5) dalam sebagai berikut: Suatu hasil seni selain merefleksi diri seniman penciptanya juga merefleksi lingkungannya (bahkan diri seniman itupun terkena pengaruh lingkungan pula). Dari uraian tersebut dapat dilihat antara seniman dan lingkungannya berkaitan erat sebab seniman juga adalah makhluk sosial yang tidak lepas dari faktor-faktor obyektif yang melingkupnya. Begitu pula halnya dengan pencipta alami bahwa faktor lingkungan dilahirkan dan dibesarkan sangat berpengaruh dalam kehidupan kita. Pencipta tinggal di Bali dan di besarkan di lingkungan masyarakat Bali, adat, agama, dan seni saling berkaitan erat antara satu dengan lain, dalam suatu tatanan gerak kehidupan masyarakat sehari-hari.

Berdasarkan pengalaman dan pengamatan dalam kehidupan sehari-hari. Dari sekian banyak obyek yang terdapat di sekitar lingkungan, pencipta tertarik dengan kehidupan wanita dan aktivitas yang dilakukannya, teristimewa peranan kehidupan wanita Bali. Hal ini dilatar belakangi oleh adanya suatu tuntutan yang harus dilakukan untuk memenuhi kebutuhan hidup sehari-hari wanita dalam kehidupan sehari-hari sebagai ibu rumah tangga dan mencari nafkah 
tambahan, begitu juga halnya yang dialami oleh wanita Bali yang bertugas baik sebagai ibu rumah tangga maupun sebagai pekerja mencari nafkah ia pun tetap dituntut oleh pekerjaan adat dan agama yang mengikatnya. Dalam berbagai macam upacara adat sehari-hari yang dilakukan di Bali, peranan kaum wanita sangat diperlukan yang dimulai dari persiapan sampai upacara selesai.

Demikian ketertarikan pencipta pada aktivitas wanita dengan sikap dan gerak-geriknya menarik perhatian pencipta, sehingga memberikan dorongan estetis untuk memvisulisasikannya ke dalam bentuk karya seni lukis. Wanita Bali sebagai obyek yang mengilhami proses penciptaan karya seni, pencipta menampilkan figur wanita dengan aktivitasnya dari berbagai macam aktivitas yaitu aktivitas wanita Bali dengan adat-istiadatnya.

\subsection{Wanita Sebagai Ide}

Dalam masyarakat pada umumnya wanita mempunyai ciri-ciri tersendiri yang sering diidentifikasikan dengan keindahan. Dalam hal ini menyatakan sebagai berikut:

Untuk mengukur dari keindahan psikis yang sangat dihargai itu antara lain kehalusan, keramahan, keriangan (tidak bermuka macam), humor atau suasana hati yang positif, kelembutan dan tidak jahat. Apabila sifat-sifat yang positif ini banyak ditinggalkan oleh seorang wanita atau tidak dimilikinya, maka wanita itu disebut tidak menarik (Kartini Kartono, 1977: 300)

Dari uraian tersebut diperoleh gambaran bahwa wanita lebih sering dihadapkan pada ciri kelembutan hati dan sifat-sifat ini banyak dituntut oleh lawan oleh lawan jenisnya sebagai tuntutan sosial.

Dari pengalaman dan pengamatan yang berhasil pencipta serap yaitu aktivitas wanita Bali dengan sikap dan gerak geriknya menarik perhatian, karena dalam aktivitas yang dilakukan terlihat adanya kerja sama dan gotong-royong . Hal ini dapat dilihat pada saat mempersiapkan sesaji, merangkai janur, melaksanakan upacara dan lain sebagainya. Mereka melakukannya penuh suka cita dan tanpa pamrih. Selain itu pula pakaian yang dikenakannya berwarna-warni serta bermacam ragam menambah suasana yang lebih menarik ditambah latar belakang alam yang mendukungnya, maka sangat memberikan dorongan estetis pada pencipta untuk divisualisasi- kan ke dalam bentuk karya seni lukis.

\subsection{Konsep Perwujudan}

Bentuk-bentuk obyek yang pencipta ungkapan adalah wujud wanita bali dengan mengeksploitasi kehidupannya sehari-hari dan budaya bali dengnan segala pesona dan keindahannya. Bentuk obyeknya tidak persis menurut perwujudan obyek aslinya atau penggambaran obyek sudah berbeda dengan apa yang dilihat dan telah mengalami penambahan dan pengurangan. Pendeformasian dan penyederhanaan bentuk selalu pencipta lakukan, sesuai dengan ungkapan curahan perasaan bathin dan rasa estetis, dengan tujuan memperoleh kebebasan dan keleluasaan membentuk dan menyusun obyeknya. Mengenai deformasi seperti yang ungkapkan oleh Dick Hartoko (1986: 15-17) yaitu sebagai berikut: Justru karena keanehan, justru karena deformasi kita temukan kembali kenyataan,ini berarti bahwa kesenian dapat membuka bagi kita sebuah pandangan terhadap dunia nyata. Tidak meniru kenyataan melainkan menampilkan dengan cara lain (Dick Hartoko 1986: 28)

\subsection{Tinjauan Sumber Tertulis}

Dalam merealisasikan penciptaan ini baik secara teoritis maupun praktis, maka diperlukan sumber-sumber tertulis yang mendukung serta melandasi konsep karya. Adapun sumber ini pencipta peroleh melalui buku-buku literatur, melihat karya-karya seni yang ciptakan oleh seniman-seniman terdahulu, menyimak melalui media elektronik, majalah, koran, terkait dengan fenomena-fenomena kekinian. Hal-hal yang diuraikan dalam kajian sumber kepustakan ini, yaitu membahas masalah-masalah seni yang berkaitan dengan judul dan uraian tentang tema sebagai acuan dalam berkarya

\subsubsection{Pengertian Seni Lukis}

Diterangkan dalam buku Tinjauan Seni, "Seni Lukis adalah suatu pengungkapan pengalaman estetik yang tumpahkan dalam bidang dua dimensional dengan menggunakan garis, warna, serta dapat menggunggah perasaan orang lain yang menikmati" (Soedarso, 1990: 11). Dalam penciptaan karya seni khususnya karya lukis tidak lepas dari struktur seni rupa. Struktur adalah suatu cara untuk menyusun suatu bagian - bagian mendapatkan suatu bentuk. 
Dalam Pengantar Dasar IImu Estetika Jilid 1 dinyatakan "merupakan aspek-aspek dari keseluruhan karya yang utuh dan harmonis " (Djelantik, 1990: 32).

Unsur-unsur visual yang diungkapkan dalam karya pencipta adalah bentuk, bidang, garis, warna, tekstur, dan ruang. Bentuk atau wujud yang ditampilkan adalah wujud Wanita Bali dengan aktivitasnya dalam berbagai macam adegan.

\section{a. Garis}

Garis berfungsi sebagai pembentuk obyek, pembagi ruang. Sudarmaji dalam (Susanto,2011: 148) menerangkan lebih jelas tentang garis sebagai berikut: Jika garis digores dengan jujur mengikuti kata bathin akan ditemukan identifikasi seseorang, ia menjadi personel. Dengan garis dapat lahir bentuk, tapi juga bisa mengesankan tekstur, nada, nuansa, ruang, volume, kesemuanya melahirkan suatu perwatakan. Dengan demikian garis mampu memberikan identifikasi bagi seseorang bila digoreskan secara jujur. Pada karya saya garis berfungsi sebagai pembentuk obyek, pembagi ruang, serta memberi kesan gerak Garis. Sebagai bentuk, mengandung arti lebih dari pada titik karena dari bentuknya sendiri garis menimbulkan kesan tertentu pada pengamat. Garis kencang memberikan kesan rasa berbeda dari pada garis yang membelok atau melengkung. Yang pertama memberikan kesan kaku, keras dan yang berikutnya memberi kesan luwes maupun lembut (Dharsono, 2004: 40)

b. Warna

Warna menurut sudarmaji fungsi warna ada 3 macam disebutkannya: Yang pertama punya fungsi semacam perjanjiaqn misalnya bendera merah putih melambangkan penyerahan, fungsi kedua mewakili kenyataan optisme umpamanya cairan merah untuk darah atau hijau untuk dedaunan, fungsi ketiga warna itu mewakili dirinya sendiri. Dalam kaitanya fungsi warna di atas, warna-warna dalam karya saya adalah pada fungsi ketiga, yaitu warna yang mewakili diri sendiri karena warna tersebut digunakan untuk keselarasan dan pengkomposisian obyekobyeknya (Susanto, 2012: 113)

\section{c. Tekstur}

Tekstur menurut Soegeng dalam (Dharsono 2004: 48) terdapat dalam karya saya karena pemakaian pasta pengering dalam jumlah yang berlebihan sehingga mengkristal dan menimbulkan efek tekstur (Mikke Susanto 2011:20) menjelaskan tekstur atau barik adalah niali raba atau kualitas permukaan yang dapat dimunculkan dengan manfaatkan kanvas, cat atau bahan-bahan seperti pasir, semen, dan lain-lain

\section{d. Ruang}

Menurut Mikke Susanto (2011: 338), ruang merupakan istilah yang dikaitkan dengan bidang dan keluasan, kemudian muncul istilah dwimatra dan trimatra.

Dalam seni rupa orang sering mengaitkan ruang adalah bidang yang memiliki batas atau limit, walaupun kadangkadang ruang bersifat tidak terbatas dan tidak terjamah. Ruang juga dapat dikaitkan secara fisik adalah rongga berbatas maupun tidak berbatas. Pada suatu waktu, dalam hal berkarya seni, ruang tidak lagi dianggap memiliki batas secara fisik. Menurut Dharsono (2004: 53) menyatakan bahwa: ruang dalam unsur rupa merupakan wujud tiga matra yang mempunyai: panjang, lebar, dan tinggi (punya volume). Untuk meningkat dari satu warna ke warna lebih tinggi dibutuhkan waktu. Sehingga untuk memahami dan menghayati unsur-unsur rupa dalam berkarya seni tetap dibutuhkan waktu.

\section{e. Bidang}

Shape atau bidang adalah area. Bidang adalah berbentuk karena ada dua atau lebih garis yang bertemu (bukan berhimpit). Dengan kata lain, bidang adalah sebuah area yang dibatasi oleh garis, baik oleh formal maupun garis yang sifatnya ilusif, ekspresif atau sugestif (Mikke Susanto, 2011: 55). Sedangkan menurut (Dharsono 2004: 40), shape adalah suatu bidang kecil yang terjadi karena dibatasi oleh sebuah kontur (garis) dan atau dibatasi oleh adanya warna berbeda atau oleh gelap terang pada arsiran atau tekstur. 


\subsubsection{Prinsip - Prinsip Penyusunan dalam karya seni Lukis}

Prinsip seni adalah serangkaian kaidah umum yang sering digunakan sebagai dasar pijakan dalam mengelola dan menyusun unsurunsur seni rupa dalam proses berkarya untuk menghasilkan sebuah karya seni rupa. Prinsip tersebut meliputi:

a. Kesatuan

Kesatuan atau unity adalah kesatuan yang diciptakan lewat sub azaz dominasi dan subordinasi (yang utama dan kurang utama) dan koheren dalam komposisi karya seni (Susanto, 2011: 416). Prinsip kesatuan ini menekankan pada integritas jalinan konseptual antara unsur-unsurnya. Kesatuan dapat dicapai dengan pengulangan penyusunan elemen-elemen visual secara monoton. Cara lain untuk mencapai kesatuan adalah dengan cara pengulangan untuk warna atau arah gerakan goresan.

\section{b. Keseimbangan}

Keseimbangan atau balance adalah penyesuaian materi-materi dari ukuran berat dan memberi tekanan pada suatu komposisi dalam karya seni (Susanto, 2002: 20). Keseimbangan dapat dicapai dengan dua macam cara yaitu dengan keseimbangan simetris dan keseimbangan asimetris.

Keseimbangan simetris menggunakan sumbu pusat di antara bagian-bagian tersusun dengan bentuk kurang lebih mencerminkan satu dengan yang lain. Keseimbangan simetris mengesankan perasaan formal atau stabil sedangkan keseimbangan asimetris sering disebut keseimbangan informal. Keseimbangan tidak dicapai menggunakan sumbu pusat, melainkan dengan menggunakan warna gelap terang untuk membuat bidang-bidang tertentu lebih berat secara harmonis dengan bidang yang lain.

\section{c. Ritme}

Dalam seni rupa ritme/irama ialah suatu pengulangan yang secara terus menerus dan teratur dari suatu unsur atau unsurunsur. (Sidik, 1979: 48) Ritme dapat berupa pengulangan bentuk atau pola sama tetapi dengan ukuran bervariasi. Garis atau bentuk dapat mengesankan kekuatan visual yang bergerak di seluruh bidang lukisan.

\section{d. Harmoni}

Harmoni atau keselarasan adalah tatanan ragawi yang merupakan produk transformasi atau pemberdayagunaan ide ide dan potensi-potensi bahan dan teknik tertentu dengan berpedoman pada aturan-aturan yang ideal (Susanto, 2011: 175). Harmoni juga bisa ditimbulkan dari adanya kesatuan yang mengandung kekuatan rasa yang ditimbulkan karena adanya kombinasi unsur-unsur yang selaras antara lain rasa tenang, gembira, sedih, haru dan sebagainya.

e. Proporsi

Proporsi menurut (Susanto, 2011: 320) dalam Diksi rupa adalah hubungan antar bagian, serta bagian dan kesatuan/keseluruhannya. Proporsi berhubungan erat dengan ritme, keseimbangan dan kesatuan.

\section{f. Ekspresi}

Ekspresi merupakan maksud, gagasan, perasaan, kemampuan ide yang diwujudkan dalam bentuk nyata (Susanto, 2011: 116).

\section{g. Limitasi}

Dikaitkan dengan limitasi yang terdapat dalam prinsip seni rupa yaitu pembatasan yang dilakukan sedemikian rupa terhadap unsur-unsur yang ditetapkan kedalam sebuah karya untuk mendapatkan proporsi yang ideal.

\subsubsection{Tinjauan Sumber Lain}

Dalam kajian sumber ini uraikan tentang peran serta beberapa karya seni lukis yang secara tidak langsung memberi masukan atau pemahaman dalam mendukung ide, pencipta, baik berupa konsep karya jadi maupun secara teknik. Dioeroleh melalui pengamatan atau pameran karya seni lukis serta tulis-tulisan seni ditampilkan dalam katalog. Ada beberapa karya yang menjadi sumber kajian yaitu 


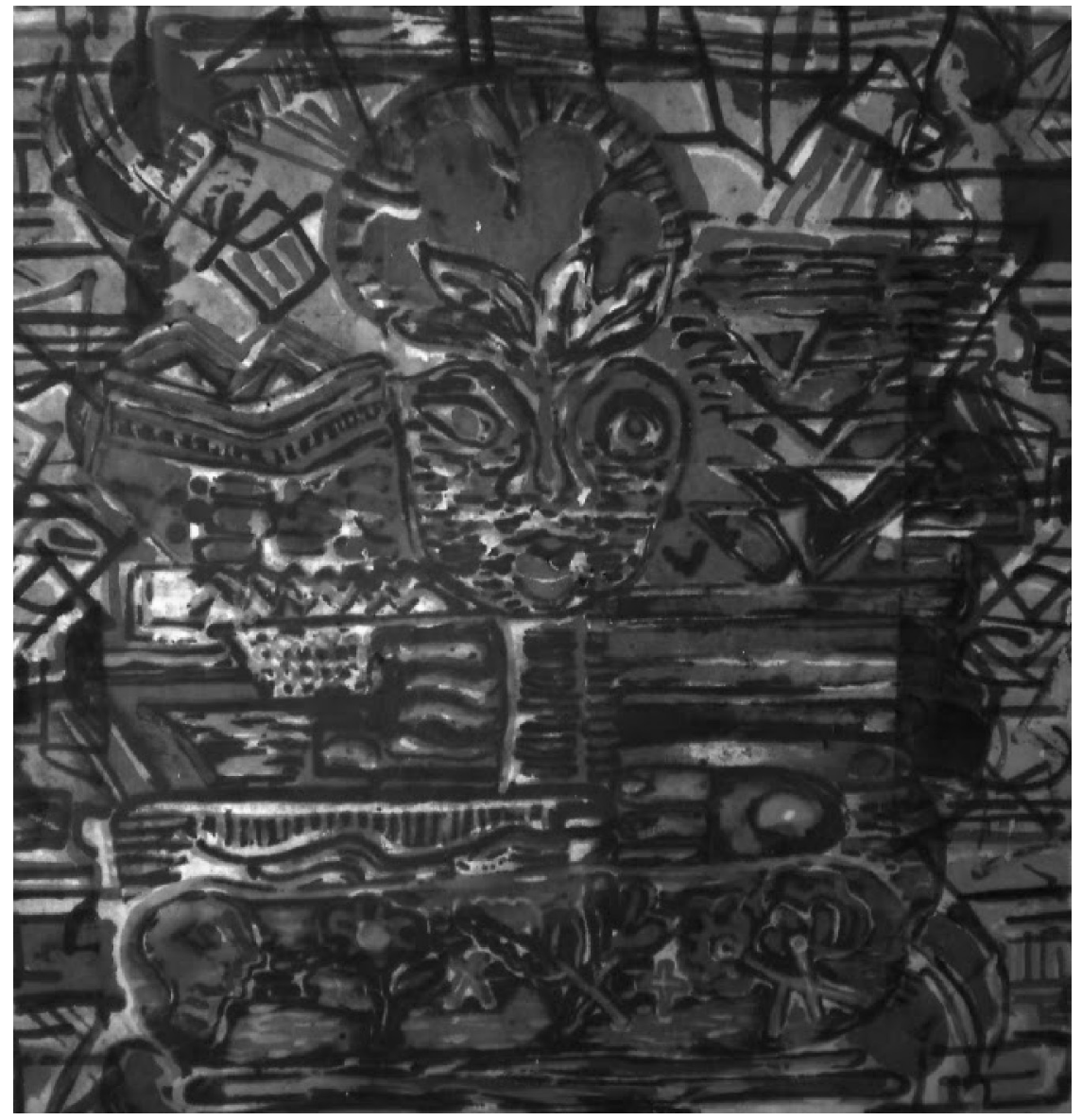

Foto 1

Karya Seni Grafis Teknik Cetak saring

Agus M. Utomo, 26 april 2016

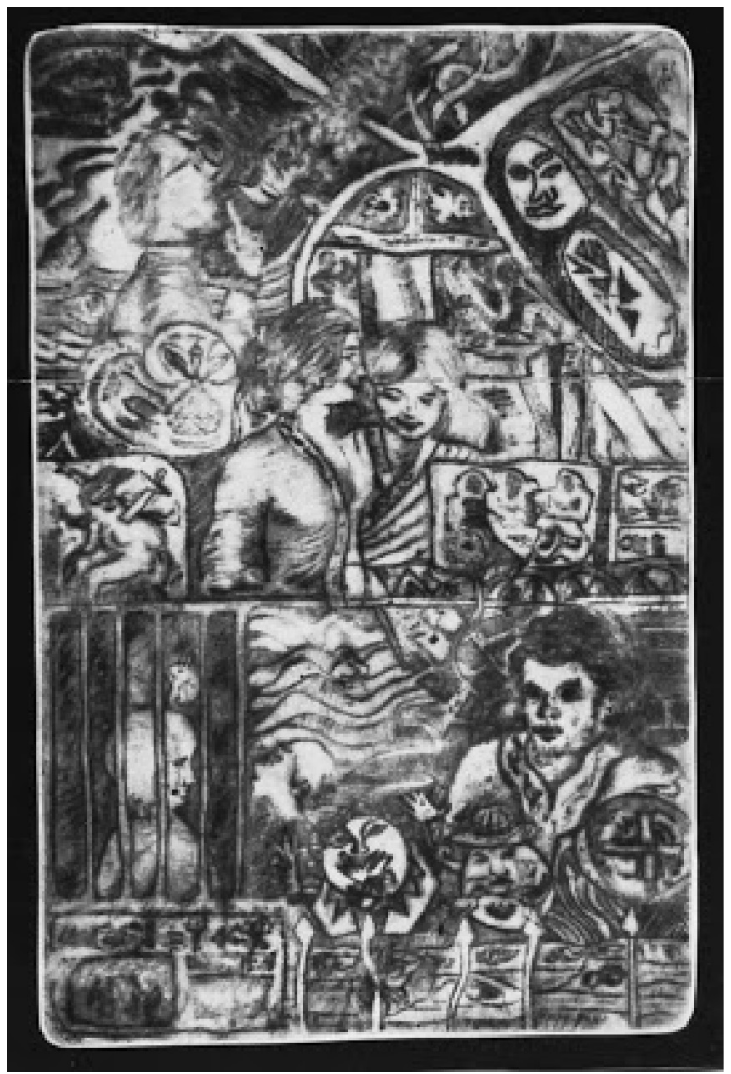

\subsection{Wujud Karya}

Wujud karya merupakan bentuk visual dari karya seni lukis dengan mengangkat tema Wanita Bali sebagai insipirasi dalam karya seni lukis. Dingkap melalui kreatifitasi pencipta dalam menanggapi suatu objek serta situasinya yang dipresentasikan melalui rasa estetis pencipta di atas bidang dua dimensional

Dalam penciptaan karya seni lukis terdapat dua aspek yang berperan penting di dalamnya, yaitu aspek ideoplastis dan aspek fisikoplastis. Aspek ideoplastis adalah hal-hal yang menyangkut tentang ide, gagasan, atau konsep pencipta yang menjadi isi dari perwujudan karya, sedangkan aspek fisikoplastis adalah hal-hal yang menyangkut tentang teknik penciptaan serta penerapan unsur-unsur seni rupa atau elemenelemen visual seni lukis.

Foto 2 Karya seni Judul "Feodal"tahun 1979

Teknik Intaglio - drypoit 


\subsubsection{Aspek Ideoplastis}

Aspek ideoplastis merupakan suatu gambaran tentang ide atau gagasan yang merupakan landasan sebagai dasar pemikiran yang merupakan ekspresi,dalam menuangkan ke media seni lukis. Pengekspresian dorongan bathin yang timbul dari pengalaman serta harapan yang telah mengalami suatu pengamatan serta perenungan. Perwujudan ekspresi yang memberikan nuansa dinamis yang memiliki rasa sehingga dapat mencapai sebuah karya seni lukis tampak lebih berbobot dan berkarakter tanpa meninggalkan unsur keartistikan.

\subsubsection{Aspek Fisioplastis}

Aspek ini menguraikan tentang aspek pendukung dalam sebuah karya, berupa elemen-elemen dasar dan prinsip dalam seni lukis yang dapat mendukung sumber ide dalam mewujudkan karya seni.

\subsubsection{Deskripsi karya}

Pada bagian ini diurai tentang deskripsi karya dari aspek ideoplastis, aspek fisioplastis serta pemaknaan yang terkandung dalam karya adalah sebagai berikut:
Melukiskan kegiatan para wanita di Bali sehabis menyelesaikan pekerjaan harian rumah tangga, mereka juga aktif dengan kegiatan di pura yaitu diantaranya sebagai penari pengayah dalam kegiatan ritual keagamaan. Sebelum Pentas, menggambarkan tiga orang penari yang tengah berdandan untuk persiapan pentas. Penataan rambut untuk tari Legong sebenarnya cukup simple. Rambut hanya dijempit di atas, kemudian dipasang mahkota/badhong yang penuh dengan bunga kamboja, dua sudah mempersiapkan wajah penari dengan senang dan gembira yang kerja tata rias penari sebelum pentas.

Dalam pengkomposisi di sini mengacu pada posisi asimetris sehingga kelihatan beriirama warna yang digunakan dominan warna orange, hijau dan kuning karena mencerminkan suasana pagi hari, pada pentas di buat untuk menunjang gerak atau aktivitas wanita. Warna biru di yakni pada kain dan hiasan kepala si penari. Warna kuning dan coklat muda menjadi unsur warna dominan. Latar belakang yang berwarna coklat dan kuning.

Makna karya sebelum pentas adalah saling membantu sebagai wujud saling menolong satu sama lain dalam kehidupan masyarakat, segala

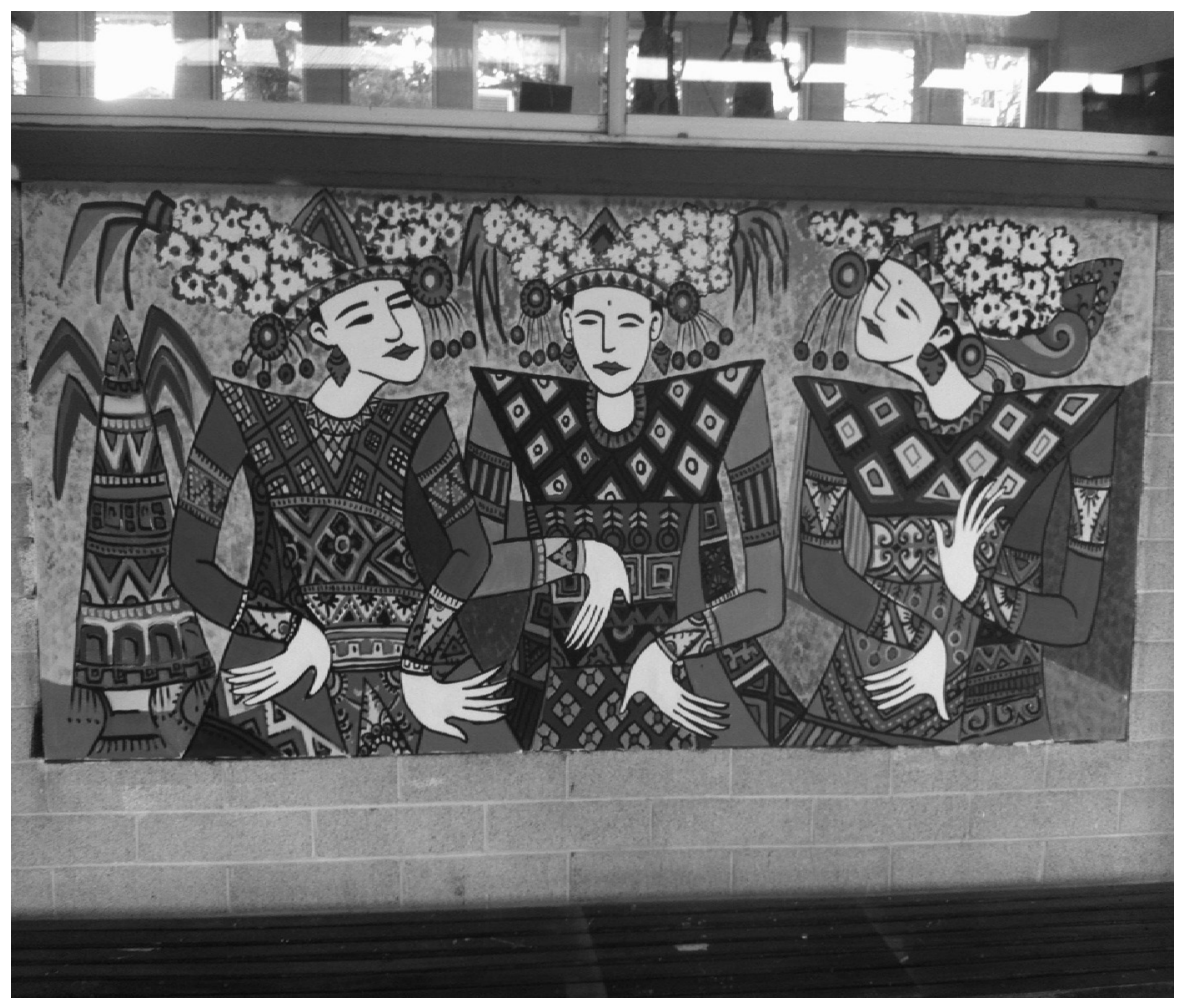

Judul ; Kegiatan di Pura.

$100 \times 100 \mathrm{~cm}$, Mixmedia

Tahun 2016 
sesuatu tidak dapat dikerjakan sendiri, mereka selalu mengenal yang namanya tolong menolong satu dengan yang lain.

\section{PENUTUP}

\subsection{Kesimpulan}

1. Terciptanya sebuah karya seni disebabkan oleh adanya kebutuhan seniman untuk mengekspresikan pengalaman estetis, yang tidak terlepas dari pengaruh dalam dan luar diri di seniman, didukung oleh faktor-faktor antara lain, timbulnya ide atau gagasan, pengalaman, penguasaan, teknik, intelektual, dan penghayatan sebagai proses terwujudnya karya seni.

2. Dalam karya lukis mixmedia ini aktivitas wanita merupakan gagasan awal. Teristimewa peranan kehidupan Wanita Bali sehari-hari. Hal tersebut dilatar belakang oleh adanya tuntutan yang harus dilakukan oleh kaum wanita Bali untuk memenuhi kebutuhan hidupnya seharihari dan menjalani adat-istiadat yang meningkatnya. Selain itu hal-hal yang menarik terdapat pada wanita secara fisik memiliki bentuk tubuh indah dengan gerak-gerik yang luwes dan secara simbolik memiliki sifat-sifat kelembutan, kehalusan, cinta kasih, tanpa pamrih dan lain sebagainya.

3. Untuk mewujudkan gagasan ini tentu disesuaikan dengan pemilihan media dan penguasaan teknik. Adapun pilihan pencipta adalah melalui media seni lukis. Teknik yang digunakan ialah mixmedia dengan sarana perpaduan teknik batik dengan lukis cat acrilic.

4. Bentuk yang pencipta tampilkan adalah wujud sosok wanita. Pendormasian dan penyederhanaan bentuk selalu pencipta lakukan, sesuai dengan ungkapan per- asaan batin dan rasa estetis dengan tujuan memperoleh kebahasan dan kelelusaan membentuk dan menyusun obyeknya.

5. Dapat mengembangkan gagasan atau ide wanita Bali kedalam seni lukis dengan berbasis teknik batik. Dekoratif dalam lukisan tradisional Bali, misalnya Ubud, Batuan

6. Teknik mixmedia dengan menggunakan sarana teknik batik maka penulis ingin memvisualisasikan karya seni lukis dalam teknik mixmedia

7. Wanita Bali divisualisasikan pada karya seni lukis dengan teknik mixmedia dengan warna batik pencipta mengekspresikan ide melalui karya seni lukis, dengan bidang yang ditekuni.

\subsection{Saran-Saran}

Dalam pembuatan karya lukis ini masih banyak pencipta rasakan kekurangan-kekurangan, pencipta harapkan dapat tetap berguna bagi kepentingan perkembangan karya lukis. Dalam proses kreatif ini tidaklah tertutup kemungkinan untuk terus berkembang baik secara tema maupun tekniknya.

Di akhir penulisan ini pencipta sangat berharap semoga karya ini dapat memberikan manfaat bagi masyarakat pencita seni pada umumnya dan perkembangan seni lukis di Indonesia khususnya

Pencipta berharap sebagai pekerja seni intelektual juga bisa memperhatikan sumber daya yang sudah ada untuk diberdayakan dan dapat menciptakan karya-karya baru yang inovatif dan berguna di masyarakat. Dengan modal pemikiran yang matang maka karya akan tercipta dengan baik dan berkualitas. Semoga dengan adanya deskripsi ini dapat digunakan sebagai pemicu kreatifitas dan kemauan untuk berkarya yang lebih baik lagi. 


\section{DAFTAR PUSTAKA}

Soedarso Sp,1990. Tinjauan Seni: Sebuah Pengantar untuk Apresiasi Seni, Suku Dayar Sana. Yogyakarta

Hermanu, 1988. (Studi Tentang Gaya Dekoratif Pada Seni Lukis Indonesia Modern Karya Abas Alibasyah, Irsam, Hatta Hambali, dan Batara Lubis), Skripsi sarjana tidak diterbitkan, STSRI "ASRI", Yogyakarta

Mikke Susanto,2002. Diksi Rupa: Kumpulan Istilah Seni Rupa, Kanisius, Yogyakarta 2003. Membongkar Seni Rupa. Yogyakarta: Penerbit Jendela dan Buku Baik

Anton M.Moeliono, 1990. Kamus Besar Bahasa Indonesia, Dep.Dik.Bud., Balai Pustaka.Jakarta

Devi,ferdiyanto,2003.Ars Multiplicata Catalog Pameran Seni Grafis oleh 12 Mahasiswa Seni Grafis ITB. Jakarta: gasar offset

Sabana Setiawan, 2000.Peranan Seni Grafis Dalam Perkembangan Seni Rupa Indonesia. Yogyakarta : Diklat Mata Kuliah Tinjauan Seni Grafis ISI

Napsurudin, drs, dkk. 1996. pelajaran pendidikan seni.Jakarta : Yudhistura

Sidik Fajar,1979. Desain Elementer. Yogyakarta : STSRI "ASRI Yogyakarta"

P.Mulyadi,1996. Pengetahuan Seni. Surakarta : UNS Press

Sony Kartika, Dharsono.2004.Seni Rupa Modern. Bandung : Rekayasa Sains

Djelantik,1990. Dalam Pengantar Dasar Ilmu Estetika Jilid 1. Bandung

Dick Hartoko,1984. Manusia dan Seni , pn. Yayasan kanisius. Yogyakarta

Hassan shadily,1980. Ensiklopedia Indonesia, Ichtiar Baru-Van Hoeve.Jakarta

Apin dan Baharrudin, 1989.Ensiklopedia Nasional Indonesia Jilid 6, Jakarta

Kartini Kartono ,1977. Psikologi Wanita, Alumni, Bandung

M.Dwi Marianto, 1988. MFA. Drs.,Seni Cetak Cukil Kayu, Pn Kanisius. Yogyakarta,.

Sudarmaji, 1973 Dasar-Dasar Kritik Seni Rupa, STSRI "ASRI" Yogyakarta.

Dendy Sugono, 2008. Kamus Bhasa Indonesia. Jakarta : Pusat Bahasa.

Tim Penyusunan. 1989. Ensklopedia Nasional Indonesia Jilid 6. Jakarta : PT. Cipta Adi Pustaka http://goesmul.blogspot.co.id/2012/03/seni-grafis.html 